Firm Heterogeneity and Market Selection in Sub-Saharan Africa: Does It Spur Industrial Progress?

Admasu Shiferaw

Follow this and additional works at: https://scholarworks.wm.edu/aspubs

Part of the Economics Commons 


\title{
Firm Heterogeneity and Market Selection in Sub-Saharan Africa: Does It Spur Industrial Progress?
}

\author{
ADMASU SHIFERAW \\ Institute of Social Studies, The Hague
}

\section{Introduction}

The poor economic performance of sub-Saharan Africa is perhaps best revealed in its fragile manufacturing sector. The region has experienced a declining manufacturing value added to gross domestic product (GDP) ratio during the 1990s, leading some researchers to believe that deindustrialization is taking place in Africa (Noorbakhsh and Paloni 1998; see fig. 1). ${ }^{1}$ Although the region has never been an important player in export markets, its share in the export of manufactures originating from the developing world has declined from about $5 \%$ in the 1970 s to less than $2 \%$ in recent years. Figure 2 shows that it is also the only region in the world that does not exhibit the global transition in the technological composition of exports from natural resource based and low technology products to that of high technology commodities. Such transitions indicate, despite some limitations, the technological capabilities and competitiveness of economies (Lall 2001).

The literature provides several macro level explanations for the poor industrial performance in most developing countries. These include such structural factors as small domestic markets, dependence on imported inputs/capital, low levels of human capital, and poor infrastructure (Tybout 2000). Other factors relate to government policies affecting macroeconomic and political stability. There is also little disagreement that these problems have been more pervasive in sub-Saharan Africa. This study, however, focuses on the micro processes that underlie the performance of manufacturing industries in subSaharan Africa, an inquiry that only began in earnest since the mid-1990s following the improvement in the availability of micro data.

I am grateful to Arjun Bedi, Jan Willem Gunning, Peter Knorringa, Remco Oostendorp, and Rob Vos for helpful comments. I also would like to thank seminar participants at the Tinbergen Institute, Amsterdam, in April 2005. The article has benefited substantially from the suggestions of two referees and John Strauss. All remaining errors are mine.

${ }^{1}$ The difference in the mean and median shows that the distribution of manufacturing value added to GDP ratio has a positive skew.

(C) 2007 by The University of Chicago. All rights reserved. 0013-0079/2007/5502-0006\$10.00 


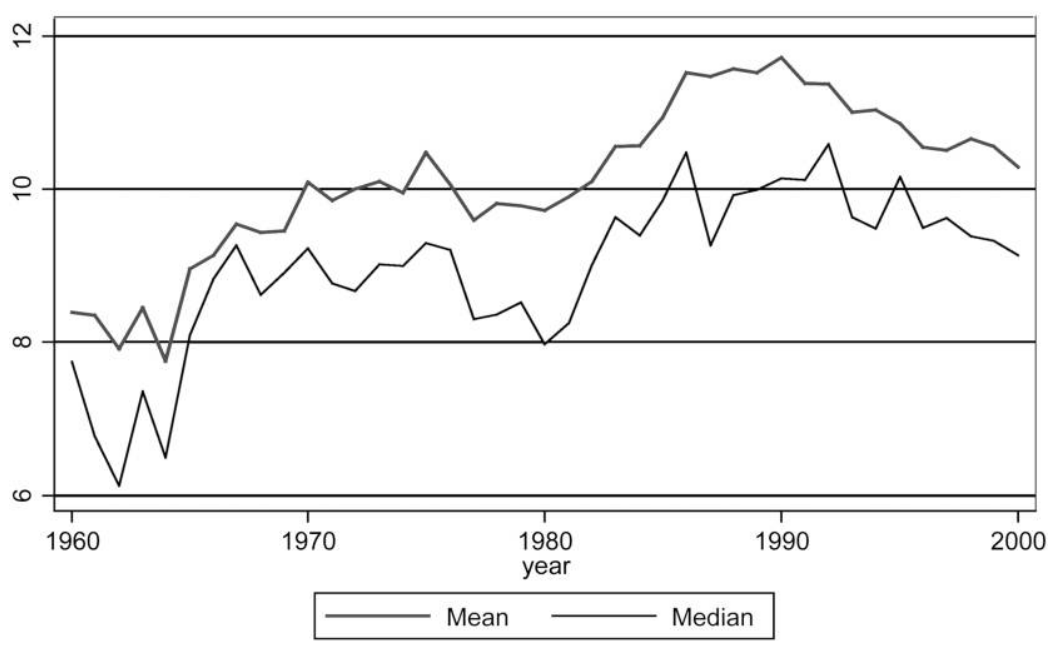

Figure 1. Africa: manufacturing value added to GDP ratio

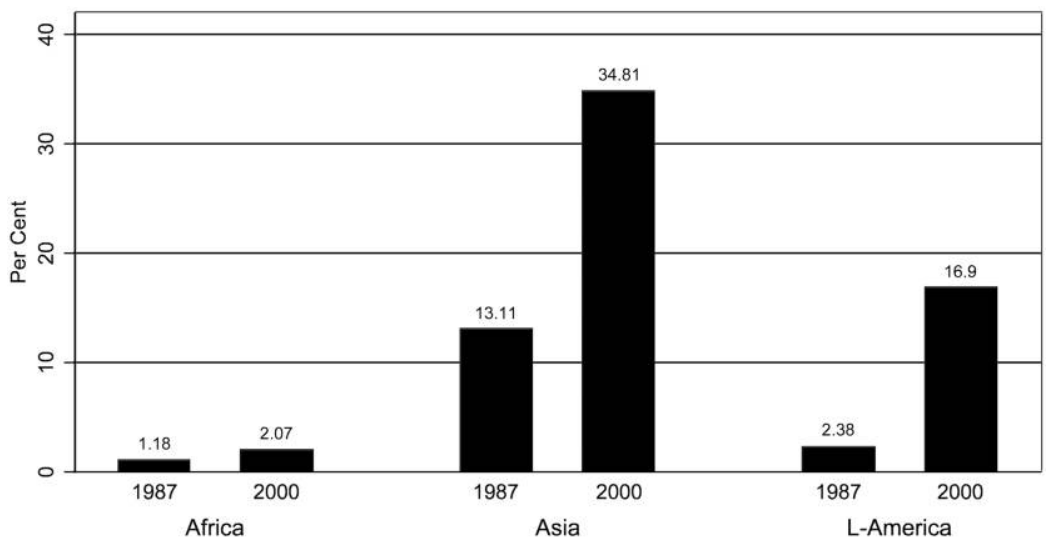

Figure 2. Share of high technology commodities in export of manufactures

A recent body of theoretical and empirical literature argues that hindering the micro processes of firm dynamics in terms of entry, growth, and exit tends to restrain aggregate-level productivity growth if such processes are indeed driven by underlying efficiency differences. In other words, even in the absence of scale economies, industries could experience productivity growth if technological heterogeneity and market selection predispose more productive firms to survive and expand while forcing inefficient ones to contract and exit. According to this argument, sluggish industrial growth in sub-Saharan Africa and other developing countries is partly explained by dysfunctional markets that create entry barriers for small firms and tolerate inefficient incumbents (Collier and Gunning 1999). In his review of manufacturing firms in devel- 
oping countries, Tybout $(2000,25)$ remarks: "If extensive regulations and taxation combine with credit market problems to keep small firms from challenging their entrenched larger competitors, we should observe few firms graduating from informal to formal status. Further, those firms that graduate should show relatively little mobility up the size distribution and market shares should be relatively stable among the largest firms."

Earlier attempts to test these hypotheses in Africa find high rates of producer turnover in the micro and small enterprises sector with growing firms standing better chances of survival (McPherson 1995; Liedholm and Mead 1999). While this suggests a competitive environment, their other observations, such as most firm closures happening for nonbusiness reasons, the exit hazard not decreasing with firm size, and the rare graduation of firms to the formal sector (with 10 workers or more), imply that firm dynamics in Africa may not be strongly driven by market selection. Recent studies that focus only on the manufacturing sector but with broader range of firm size find that small firms grow faster than larger ones and that the exit probability is higher among small and inefficient firms supporting the implications of market selection models (Gunning and Mengistae 2001; Frazer 2005; Söderbom, Teal, and Harding 2006). However, key assumptions of market selection models, particularly on the reallocation of resources and the contribution of producer turnover, remain unexplored in sub-Saharan Africa mainly because of the absence of reliable industrial census data and partly due to the confidentiality problem that restricts access to such data (Gunning and Mengistae 2001). This study makes a contribution toward filling this gap. Using a census-based panel of manufacturing establishments from Ethiopia, it examines the heterogeneity in plant-level productivity and whether this heterogeneity drives observed patterns of entry, exit, and survival. Most importantly, it estimates the magnitudes of producer turnover and reallocation of resources from less efficient to more efficient producers, and their respective contributions to industry-level productivity growth. In doing so, the article addresses two central questions: How strongly do African markets, as represented by Ethiopia, select efficient firms? Does market selection play an important role for long-term industrial progress?

The article is organized as follows. Section II briefly reviews the theoretical and empirical literature on market selection and productivity dynamics. Section III provides background details on Ethiopian manufacturing and discusses the nature of the data and estimation methods. Section IV presents the evidence from Ethiopian manufacturing on productivity dynamics and producer turnover. Section V discusses the decomposition of aggregate productivity growth into various components. Section VI concludes the article. 


\section{Literature on Market Selection and Productivity Dynamics}

The literature provides several explanations for plant-level technological heterogeneity and how it relates to aggregate productivity. Some authors follow a general equilibrium framework while others use partial equilibrium analysis. In the general equilibrium analysis attention is paid either to the rate at which new products are introduced to the economy (Lucas 1993) or to the rate at which low quality products are progressively replaced by higher quality products (Stockey 1991).

Significant progress has also been made in explaining firm heterogeneity in productivity using dynamic partial equilibrium models, which provide the theoretical framework for empirical studies based on micro panel data. In the passive learning model suggested by Jovanovic (1982), for instance, producers start to learn about their (time-invariant) endowments of relative efficiency during the first few years upon entry. Firms that receive positive productivity shocks would survive the market and grow in size while relatively inefficient firms would contract and eventually exit. The model predicts persistence at the upper end of the productivity distribution as it is dominated by efficient large firms that have realized their true relative efficiencies. However, the lower tail of the distribution would be marked by a state of flux, that is, with entry and exit of small and relatively inefficient firms.

Hopenhayn (1992) also provides a model in which productivity differences persist over time mainly because the competitive advantages acquired by firms (for whatever reason) do not decay quickly. In this model, a large productivity shock in the current period increases the probability that the firm receives a larger productivity shock next period. The Hopenhayn (1992) model suggests that simultaneous entry and exit of firms with offsetting results would take place with sufficiently low sunk cost of entry. Hence, policies that increase entry barriers tend to reduce the minimum level of efficiency required to stay in the market, thereby leading to lower aggregate productivity.

These theoretical frameworks together with others like Ericson and Pakes (1995) have been used to organize empirical studies based on micro panel data. The latter often seek evidence on two major issues: the effect of heterogeneity on survival and turnover of producers, and the effect on aggregate productivity growth of producer turnover and reallocation of resources from less to more efficient producers. A review of this empirical literature has been provided in Bartelsman and Doms (2000) and Tybout (2000).

The literature reveals that within narrowly defined industries, firms exhibit remarkably large dispersion of productivity and the current relative productivity of a firm is a good predictor of its relative position in the future. Most importantly, it has been shown that firm-level heterogeneity in productivity 
and its path dependence play an important role in productivity dynamics at the industry level. Incumbents in an industry are found to be more productive than both exiters and entrants, and the latter two are largely represented at the lower tail of the productivity distribution. In Taiwanese manufacturing, for instance, entrants are less productive than incumbents in seven out of nine industries, and average productivity of exiters is less than that of continuing firms for every industry and time period studied (Aw, Chen, and Roberts 2001). Similar results are report in Baily, Hulten, and Campbell (1992) for U.S. manufacturing. However, the literature shows some divergence in the contribution of net entry for industry-level productivity growth. In Taiwan, net entry contributed between $1 \%$ and $35 \%$ of productivity growth in different industries. In the United States, net entry has no significant role for aggregate productivity growth, acting at times as a net drag (Baily et al. 1992). The latter is due to the narrow productivity gap between entrants and exiters on the one hand, and the small market share both groups of firms have on the other.

There is even stark divergence in evidence regarding the importance of the reallocation of resources from less efficient incumbents to more efficient ones. Studies from developed countries almost always report positive and significant contribution of reallocation. Baily et al. (1992) find that the reallocation of market share accounted for $30 \%-40 \%$ of industry-level productivity growth during periods of productivity improvement and helped offset sharp decline during periods of productivity loss. For U.S. firms, Bernard and Jensen (1999) report similar results in which the reallocation effect was greater than $40 \%$. For Taiwan, however, the reallocation effect was close to zero (Aw et al. 2001). In the case of Colombia, reallocation had little long-run effect on aggregate productivity growth despite important year-to-year differences (Liu and Tybout 1996). ${ }^{2}$ Both for Taiwan and Colombia the same authors find that it is rather the intrafirm productivity effect that sets the path for industry-level productivity growth. However, Pavcnik (2002) reported that about $70 \%$ of productivity growth in Chilean manufacturing is explained by reallocation of resources. In a recent paper, Petrin and Levinsohn (2004) find a positive and significant role of reallocation for Chilean firms based on an alternative decomposition method. Comparison of results is complicated by differences in decomposition methods, the weights used for aggregation and the industries studied.

\footnotetext{
${ }^{2}$ Note that their study used factor share to aggregate firm-level productivity to industry-level productivity and that the decomposition is based on productivity growth rather than level of productivity
} 
This study provides empirical evidence from sub-Saharan Africa that can be readily compared with the preceding discussion. Such an exercise has so far been hindered partly by differences in the nature and composition of samples used by existing firm-level studies from Africa. For instance, the work by Liedholm and Mead (1999) and McPherson (1995) leaves out the medium and large size categories and uses a mixture of manufacturing and service industries. While Frazer (2005) and Söderbom et al. (2006) show the importance of efficiency for firm survival, the link between firm and industry dynamics has not been established. Their samples are also drawn from a few manufacturing industries and tend to be heavily represented by large firms. Using similar data, van Biesebroeck (2005) goes further to investigate firm size and productivity dynamics using transition matrices and decomposition of aggregate productivity growth based on a panel data of surviving firms. He finds persistence in the distribution of firm size and efficiency, and that intrafirm productivity growth dictates industry-level productivity growth much like the case in other developing and developed countries. The analyses of firm and industry dynamics in this article rely on census-based panel data that permit not only the estimation of producer turnover and its contribution to aggregate productivity growth but also a more accurate estimation of the resource reallocation role of markets. The results are compared with benchmarks in the literature providing comparative perspective about market selection in African manufacturing. First, however, I present some brief background on Ethiopian manufacturing and the nature of the data.

\section{Ethiopian Manufacturing}

\section{A. Background}

Foreign capital played a leading role in the emergence of modern manufacturing in Ethiopia during the early twentieth century. By 1974 foreign nationals had either full or majority ownership in 52\% of manufacturing enterprises. The sector went through a radical change in the structure of ownership and production organization after the military regime took office in 1974. All medium and large scale private enterprises were nationalized and managed centrally by few corporations. The period 1974-91 was also marked by the establishment of a number of state-owned enterprises that enjoyed preferential access to credit, foreign exchange, and skilled labor. Import-substitution industrialization continued to be the main strategy, with very high tariff and nontariff barriers as compared to the previous regime.

With the coming to power of a reformist government in 1991, the country started to implement the familiar structural adjustment programs. The Investment Law, first issued in 1992 with subsequent revisions, encompasses a 
number of reform measures that constitute a major part of the country's industrial policy. These policies aim at enhancing private sector participation by permitting entry into economic activities that were reserved for the state sector, by removing caps on private investment, and by providing a range of incentives, including tax holidays. The public enterprises reform act of 1992 was also a key industrial policy reform aiming to place public enterprises on a level playing field with their private sector counterparts by removing their preferential access to factor inputs while granting them managerial autonomy. At the macro level, the government's commitment to maintaining a stable macroeconomic environment has been regarded so far as credible by the Bretton Woods institutions.

With a manufacturing value added to GDP ratio that has stagnated at about $11 \%$ since the 1980s, Ethiopian manufacturing shares most of the features observed in sub-Saharan Africa. Basic information about the state of manufacturing in Ethiopia is provided in appendix table A1. The industry and size structure of the sector reflect the dominance of low technology, consumer goods oriented industries with large proportions of small enterprises. Relatively more entrants seem to have joined the natural resources based industries (such as Food and Beverage and Wood and Furniture), ${ }^{3}$ leading to an increase in their proportion from $40 \%$ to $50 \%$ of all manufacturing establishments during the period 1996-2002. Manufacturing has increasingly become a private sector activity, mainly due to entry of new firms, which are almost entirely privately owned, coupled with the process of privatization. However, public enterprises still account for $58 \%$ of manufacturing employment in 2002, down from $85 \%$ in 1996. In terms of manufacturing value added, the share of public enterprises has gone down from $87 \%$ in 1996 to $60 \%$ in 2002.

\section{B. Data and Methodology}

Data

This study is based on establishment-level panel data compiled by the Central Statistics Authority (CSA) of Ethiopia. The CSA undertakes an annual census of manufacturing establishments that employ at least 10 persons and use power-driven machinery. The relatively small number of manufacturing establishments of the stated size and their concentration in and around the

\footnotetext{
${ }^{3}$ The Leather and Footwear industry is an exception with a declining number of enterprises, a result ascribed mainly to heightened competition from Chinese imports since 1999.
} 
capital city, Addis Ababa, has made it possible for the census to be carried out annually. ${ }^{4}$

The data contain all the relevant information for productivity analysis. Each establishment is identified by a unique ID number in combination with a region code and four-digit International Standard Industrial Classification (ISIC) code. Data are collected on labor, intermediate inputs and their import component, beginning and end of period book value for different kinds of capital, energy consumption, and other industrial and nonindustrial costs. The labor data are in terms of number of employees by broad occupational categories and not in hours of work.

In the absence of industry wholesale price indices, I used the average price firms reported for their main product to construct firm- and industry-specific price indices. I used 1996 as the base year for the industry price index (incidentally, 1995/96 is also the base year for the new consumer price index in Ethiopia). For firms with missing values on prices, the industry price index is used to deflate market values of output and inputs. The use of firm-specific prices rectifies a major problem in the estimation of firm-level productivity based on market value of output, as industry price indices gloss over firmlevel differences in mark-up pricing (Tybout 2000). The industry price index is also used to deflate input costs and capital stock. Since the time series on beginning and end of period capital stock reported by firms was not very consistent, a new series of capital stock was generated using the perpetual inventory method. Use is made of $5 \%$ depreciation rate for buildings and $10 \%$ for machinery and equipment.

As would be expected, the data were not without problems. The original number of observations was 5,167 firm-years for the period 1996-2002. During the cleanup process, 171 observations (about 3\%) were dropped for several reasons. Major reasons included missing data either on output or key inputs for productivity analysis, non-unique firm identification numbers, or cases where levels of input or output were found to be extreme outliers. However, the problem was not concentrated in particular industries or years, and hence it is hoped that the exclusion of these firms does not bias the analysis. The number of establishments included in this study increases from 605 in 1996 to 823 in 2002.

Estimation of Total Factor Productivity

The analysis in Section IV is based on the estimation of establishment-level total factor productivity (TFP) using a production function approach. The

${ }^{4}$ In advanced countries like the United States, manufacturing censuses are carried out every 5 years with sample surveys filling the intercensus periods. 
firm-level TFP is then aggregated to industry-level TFP for the decomposition exercise in Section V. An important assumption of dynamic models of industrial evolution is the relationship between productivity shock and input levels. Productivity shocks form part of the information for a firm's decision to stay in business as well as for the choice of input levels in case the firm decides to stay. The presence of such correlation between input levels and firm-specific productivity shocks that are unobservable to the researcher creates a simultaneity problem. Estimation methods that ignore this phenomenon (like ordinary least squares [OLS]) provide estimates of factor elasticities that are biased and inconsistent. Hence productivity analysis based on such estimates will also be unreliable.

Earlier attempts to solving this problem relied on using the fixed effects estimation method for panel data that sweeps away any relationship between firm fixed effects and input levels. While this method minimizes the simultaneity bias, it assumes that the firm-specific effects are time invariant. Interest, however, developed on time-varying idiosyncratic shocks, as they allow empirical tests on policy outcomes as well as on implications/assumptions of theories of industry evolution. Researchers attempted to overcome this by regressing the firm-specific effects from a fixed effects model as some function of time (see, e.g., Cornwell, Schmidt, and Sickles 1990; Battese and Coelli 1992). While this approach allows the productivity term to vary over time, it still assumes no correlation between the unobserved effects and input levels. The choice of the time function is also arbitrary and carries little economic meaning.

Olley and Pakes (1996) suggested an innovative approach using a proxy variable method. In this method investment is used as a proxy for unobserved effects. This is done by modeling investment as a nondecreasing function of productivity shock and other state variables. By inverting the investment function, a functional form is defined for estimating productivity. The OlleyPakes approach is considered to provide a better solution to the simultaneity problem compared to the fixed effects and generalized method of moments estimators as it leaves more identifying variance in inputs and exogenous variables (Griliches and Mairesse 1998). ${ }^{5}$ However, the Olley-Pakes approach requires nonzero investment and hence truncates those firms with no investment. This feature limits its application particularly to data from developing countries where nearly $50 \%$ of firms do not invest in a given period. Moreover, capital adjustment costs imply that the investment proxy may not capture the entire productivity shock.

\footnotetext{
${ }^{5}$ For a critique on this method, see Ackerberg, Caves, and Frazer (2005).
} 
Following the same strategy as Olley and Pakes (1996), Levinsohn and Petrin (2003) devised a model where intermediate inputs are used as proxy for unobservables. One important advantage of the Levinsohn-Petrin procedure is that it avoids truncating firms with zero investment since almost all firms use intermediate inputs. In addition to the data advantage, their method is also likely to pick up a substantial amount of the productivity shock, as intermediate inputs are relatively easy to adjust as compared to capital. The fact that intermediate inputs do not form part of the state variables that determine the firm's relative position in the market also makes them very good proxy variables (Levinsohn and Petrin 2003). The productivity estimates used in this study are obtained by applying this procedure on value added of Ethiopian manufacturing firms.

The production function in the Levinsohn-Petrin method has the following form:

$$
y_{t}=\beta_{0}+\beta_{l} l_{t}+\beta_{k} k_{t}+\beta_{m} m_{t}+w_{t}+\eta_{t},
$$

where $y_{t}$ represents logarithm of a firm's gross revenue or value added, $l_{t}$ the logarithms of labor and other freely variable inputs, $m_{t}$ the logarithm of intermediate inputs, and $k_{t}$ the logarithm of state variable capital. The error terms $w_{t}$ and $\eta_{t}$ represent the productivity term and a white noise, respectively.

To solve the simultaneity bias, Levinsohn and Petrin proceed by assuming demand for intermediate inputs to be a function of the state variables $k_{t}$ and $w_{t}$ :

$$
m_{t}=m_{t}\left(k_{t}, w_{t}\right)
$$

Assuming demand for intermediate inputs to be monotonically increasing in productivity $w_{t}$, equation (2) is inverted to define a functional form for $w_{t}$ as follows:

$$
w_{t}=w_{t}\left(k_{t}, m_{t}\right) .
$$

Equation (3) now expresses the unobservable term as a function of two observables, and this term is substituted in equation (1).

A final identification restriction requires the assumption of a first-order Markov process for the productivity term following Olley and Pakes (1996):

$$
w_{t}=E\left[w_{t} \mid w_{t-1}\right]+\xi_{t},
$$

where $\xi_{t}$ is productivity innovation that is not correlated with $k_{t}$, but not necessarily with $l_{t}$. For details of the algorithm, see Levinsohn and Petrin 
(2003) and for estimations using the statistical package STATA, see Petrin, Poi, and Levinsohn (2004).

The input coefficients from the semiparametric estimation highlighted above are used to construct an establishment-level TFP simply by subtracting predicted value added from actual value added. ${ }^{6}$ For better comparison across industries, the establishment-level TFP is then converted into a productivity index by comparing it relative to a reference establishment, as is done in Aw et al. (2001) and Pavcnik (2002). The analysis in Section IV is based on a TFP index constructed as follows:

$$
\begin{gathered}
\operatorname{TFP}_{i t}=\exp \left[y_{i t}-\beta^{\prime} x_{i t}\right], \\
\mathrm{PI}_{i t}=\exp \left[y_{i t}-\beta^{\prime} x_{i t}-\left(\bar{y}-\beta^{\prime} \bar{x}\right)\right],
\end{gathered}
$$

where $\mathrm{PI}_{i t}$ is productivity index for establishment $i, x_{i t}$ is a vector of inputs in logarithms, $\bar{y}$ and $\bar{x}$ are logarithms of value added and input levels of a reference plant, respectively. The value added and input levels for the reference plant are assumed to be the industry means in the base year, that is, 1996. A similar approach is followed in Section V using logarithm of TFP to facilitate estimation of productivity growth between two periods.

\section{Firm Heterogeneity and Producer Turnover}

Firm-level studies both in developed and developing countries report a considerable degree of heterogeneity among firms in a narrowly defined industry. While micro panel data allow deeper analysis of such variation, their advantage over the representative firm approach could be attenuated by doubtful data quality, particularly those from developing countries. One wonders how much of the firm-level heterogeneity is a pure measurement error and how much is technology related (Bartelsman and Doms 2000). Evidence must therefore be sought by relating heterogeneity in productivity with patterns of firm entry, exit, and survival, as well as with reallocation of market share. ${ }^{7}$

\section{Selection and Productivity Dynamics}

Like other countries, data from Ethiopian manufacturing show considerable degree of heterogeneity in firm-level efficiency. Table 1 compares selected percentiles from the productivity distribution relative to the 90th percentile.

\footnotetext{
${ }^{6}$ The estimated input coefficients are reported in appendix table A2.

${ }^{7}$ A widely used alternative method of testing market selection examines firm growth conditional on initial age and size. See, e.g., Evans (1987) for the United States and Gunning and Mengistae (2001) for Ethiopian firms.
} 
ECONOMIC DEVELOPMENT AND CULTURAL CHANGE

TABLE 1

FIRM PRODUCTIVITY RELATIVE TO THE 90TH PERCENTILE

\begin{tabular}{lrrrr}
\hline & \multicolumn{4}{c}{ Percentiles } \\
\cline { 2 - 5 } Industry & 10 th & 25 th & 50th & 75th \\
\hline Food and Beverage & 5.6 & 11.2 & 24.7 & 51.0 \\
Textile and Garments & 2.6 & 6.5 & 13.1 & 34.7 \\
Leather and Footwear & 4.0 & 10.0 & 18.0 & 38.1 \\
Wood and Furniture & 6.4 & 12.1 & 22.5 & 44.3 \\
Printing and Paper & 10.2 & 19.2 & 32.2 & 52.6 \\
Chemical and Plastics & 3.6 & 8.2 & 17.2 & 42.9 \\
Nonmetal & 4.5 & 10.5 & 20.8 & 42.9 \\
Metal & 5.0 & 10.7 & 17.7 & 39.0 \\
Light Machinery & 7.3 & 13.6 & 25.0 & 44.4 \\
Manufacturing sector & 5.3 & 11.0 & 21.8 & 45.8 \\
\hline
\end{tabular}

Source. Own computation based on CSA data.

At the level of the manufacturing sector in general, the tenth percentile is about $5 \%$ as productive as the 90th percentile, while the median firm is only $22 \%$ as productive. Apparently, the 90th percentile is also more than twice as efficient as the 75 th percentile. Industry-specific differences in this pattern of distribution are rather limited. The only exception is the Printing and Paper industry where the relative productivity of the 10th and 25th percentiles is nearly twice the respective averages across sectors, showing relatively less productivity dispersion in this industry.

The importance of this huge heterogeneity in driving the survival and exit of producers will be explored by way of constructing transition matrices following the approach in Baily et al. (1992). This method traces the movement of firms along ranks of industry-specific productivity distributions during the study period. Table 2 provides such transition over the period 1996-2002 for Ethiopian manufacturing. Firms are ranked and divided into quintiles based on productivity indices in 1996 and 2002. The most productive quintile is quintile 1 in both years, and the least productive firms are in quintile 5. The table reports the transition for the entire manufacturing sector. ${ }^{8}$ The fact that the analysis is based on an index rather than the level of productivity allows comparisons across industries and over time. The upper numbers in each cell are row proportions, and the bottom numbers in bold italics are column proportions. Accordingly, the upper numbers depict the proportion of firms from each quintile of the 1996 distribution that ended up in different quintiles of the 2002 distribution. The numbers in the bottom row (in bold italics) display the composition of firms in the 2002 distribution originating from different quintiles in 1996 as well as entrants.

8 The productivity index represents normalization through industry averages in the base year (1996). Industry-specific transition matrices can be made available by the author upon request. 
TABLE 2

RANKING OF FIRMS BASED ON UNWEIGHTED PRODUCTIVITY INDEX IN 1996 AND 2002

\begin{tabular}{|c|c|c|c|c|c|c|c|c|}
\hline \multirow{2}{*}{$\begin{array}{l}\text { Quintiles in } \\
1996\end{array}$} & \multicolumn{7}{|c|}{ Quintiles in 2002} & \multirow{2}{*}{$\begin{array}{c}\text { U.S. } \\
\text { Exit } \\
\text { Rate* }\end{array}$} \\
\hline & 1 & 2 & 3 & 4 & 5 & Exit & Row Total & \\
\hline \multirow[t]{2}{*}{1} & 38.8 & 19.8 & 9.9 & 4.1 & 1.7 & 25.6 & 100 & 14.0 \\
\hline & 28.7 & 14.5 & 7.3 & 3.0 & 1.2 & 11.3 & & 11.84 \\
\hline \multirow[t]{2}{*}{2} & 21.5 & 15.7 & 11.6 & 6.6 & 2.5 & 42.1 & 100 & 20.3 \\
\hline & 15.9 & 11.5 & 8.5 & 4.8 & 1.8 & 18.5 & & 17.11 \\
\hline \multirow[t]{2}{*}{3} & 14.9 & 14.0 & 11.6 & 9.1 & 5.8 & 44.6 & 100 & 22.5 \\
\hline & 11.0 & 10.3 & 8.5 & 6.7 & 4.2 & 19.6 & & 19.55 \\
\hline \multirow[t]{2}{*}{4} & 6.6 & 12.4 & 11.6 & 9.1 & 5.0 & 55.4 & 100 & 28.7 \\
\hline & 4.9 & 9.1 & 8.5 & 6.7 & 3.6 & 24.4 & & 25.56 \\
\hline \multirow[t]{2}{*}{5} & 3.3 & 6.6 & 12.4 & 5.0 & 13.2 & 59.5 & 100 & 32.3 \\
\hline & 2.4 & 4.8 & 9.1 & 3.6 & 9.7 & 26.2 & & 25.94 \\
\hline \multirow[t]{2}{*}{ Entry } & 12.4 & 16.6 & 19.3 & 25.2 & 26.6 & & 100 & \\
\hline & 37.2 & 49.7 & 57.9 & 75.2 & 79.4 & & & \\
\hline Column total & 100 & 100 & 100 & 100 & 100 & 100 & & 100 \\
\hline United States $^{\dagger}$ & 12.75 & 13.91 & 17.10 & 24.93 & 31.30 & & 100 & \\
\hline Entry rate & 17.56 & 21.14 & 26.12 & 31.60 & 38.34 & & & \\
\hline
\end{tabular}

Source. Author's computation.

Note. In each cell the upper number shows the proportion of firms in 1996 that ended up in various quintiles in 2002. These numbers add up to 100 across the row. The lower numbers (in bold italics) show the percentage composition of firms observed in a given quintile in 2002 originating from different quintiles in 1996. These numbers add up to 100 down the column. Unlike manufacturing censuses from developed countries, the Ethiopian data does not differentiate the exact status of exiting firms. While some of the exiters are truly dead firms, some could simply be slipping below the 10 persons employment threshold, while others are shifting their line of production to other industries in manufacturing or to an entirely different sector. Similarly, not all entrants are new firms; some are graduating into the census size category, while others are switching in from other industries or sectors. While merger is another possibility for disappearance of firms, it is very unlikely to be an important case in the Ethiopian data. * Exit rates for U.S. manufacturing are taken from Baily et al. (1992, 248, table A3) and include both switching out and death rates for the upper numbers and only firm death for the lower numbers.

† Entry rates for U.S. manufacturing are from Baily et al. (1992, 248, table A3), and they include only entry through "birth" for the upper numbers and "births and switch-ins" for the lower numbers.

The numbers at the top of each cell in table 2 show a substantial degree of persistence at the upper end of the productivity distribution while the bottom end is in a state of flux. Close to $40 \%$ of firms that were in the first quintile in 1996 managed to stay in the first quintile after 6 years. About $20 \%$ of the top-ranking firms in 1996 have moved to the second quintile in 2002. Taken together, $58.7 \%$ of firms in the most productive quintile in 1996 have managed to remain within the top $40 \%$ of firms in the 2002 productivity distribution. Firms in the second quintile in the 1996 productivity ranking also behaved similarly; 21.5\% upgraded to the top quintile in 2002 while $15.7 \%$ remained in the same position. About $48 \%$ of firms in the top two quintiles in 1996 managed to stay put in the top $40 \%$ in 2002. Being relatively more efficient, therefore, maximizes not only the probability of staying in the market but also the probability of remaining at the top of the productivity distribution. This result is consistent with the findings of most longitudinal 
studies and shows that relative productivity, no matter what its source is, tends to persist. In Baily et al. (1992), $43.3 \%$ of U.S. manufacturing firms in the first quintile maintained their position after 5 years. In total, $62 \%$ of U.S. firms in the first quintile were located in the top $40 \%$ after 5 years, showing a degree of persistence higher than in Ethiopia.

A consistent but different story emerges when we look at the lower tail of the distribution. Looking at the top numbers in the "Exit" column in table 2, we see that a remarkable $60 \%$ of the least efficient firms in 1996 have exited the manufacturing sector before 2002. Similarly, 55\% of firms in the fourth quintile have faced the same fate of exiting the market. This shows that markets are functional and exert competitive selection, an observation that runs against the popular argument that African markets tolerate inefficient firms. Table 2 shows that, although exit is not restricted among inefficient firms, the exit rate declines substantially as we go up the productivity ranks. Among the most productive firms, for instance, only a quarter have exited the market. Although productivity is not the only reason for exit, there is clear evidence that markets force inefficient producers to close down. Similar patterns are reported in Baily et al. (1992), where the share of exiting firms in the United States increases as one moves down the productivity distribution. The exit rate in Ethiopian manufacturing is, however, nearly twice as high as in the United States in each quintile.

Table 2 provides another important piece of information about firm entry. Nearly 500 firms have joined Ethiopian manufacturing since 1996, of which $26.6 \%$ and $25.2 \%$ are in the bottom fifth and fourth quintiles in 2002, respectively. In other words, more than half of the entrants since 1996 are located at the bottom $40 \%$ of the productivity distribution in 2002. This is consistent with the assumptions of the passive learning model according to Jovanovic (1982) that new firms are relatively small and inefficient. For most entrants there appears to be a process of learning that precedes either upgrading in the productivity ladder or exiting the market. But that is not the entire story. About $29 \%$ of entrants were also among the top $40 \%$ of firms $-12.4 \%$ in the first and $16.6 \%$ in the second quintile, respectively. It will be shown later on that the latter is more of a size effect rather than a vintage effect.

Looking at the numbers in bold italics in each row of table 2, we see that the most efficient $20 \%$ of firms in 2002 came from almost everywhere, but most, that is, about 29\%, are from the top quintile in 1996. A decreasing proportion of firms originated from the lower quintiles; for instance, only

${ }^{9}$ Notice that the transition matrices in Baily et al. (1992) are over 5 years while the discussion in this article is over 6 years. However, results remain essentially the same for a 5 -year transition. 
$2.4 \%$ of firms in the first quintile in 2002 are upgrading firms from the bottom quintile in 1996. Looking at the other tail of the distribution, we see that firms in the top two quintiles in 1996 account for less than $2 \%$ of the fifth quintile in 2002, as only a few of them descend to the bottom rank. This shows once again that efficient firms not only survive the market but also tend to stay at the top of the productivity ranking.

It is interesting to note that although entrants account for quite a significant proportion of every quintile in 2002, they are overly represented in the bottom two quintiles. Entrants account for $75 \%$ and $79 \%$ of the fourth and fifth quintiles, respectively, in 2002. Combining this information with the preceding discussion that exit is prevalent at the lower end of the distribution, it becomes obvious that most of the exiting firms are also new entrants. The numbers in bold italics in table 2 also show that the proportion of exiting firms varies inversely with the productivity ranking. Only $11 \%$ of the exiting firms are from the top quintile in 1996 while the bottom two quintiles together accounted for $50 \%$ of the exiters. The comparison of exit rates with those in U.S. manufacturing shows striking similarity. In both countries about 30\% of exiters were from the top $40 \%$ of firms while $50 \%$ of exiters came from the bottom two quintile in the initial period.

Further investigation revealed that across the productivity distribution in 2002, firms that stayed in the top quintile between 1996 and 2002 exhibit productivity that is above the average for the top quintile in 2002. This shows that firms that remain in the top quintile throughout the study period tend to be among the most productive even within the top $20 \%$. This is not, however, the case for the remaining four quintiles, in which case the quintile average is equal to the average productivity of firms from all origins in 1996. The only exception is that firms that slipped down to lower ranks from the top quintile in 1996 still remain slightly above the average productivity of the relevant quintile, revealing that relative efficiency may erode but it erodes very slowly, as pointed out by Hopenhayn (1992).

While the results discussed above are consistent with the findings of longitudinal studies from developed and developing countries, the magnitude of turnover appears to be very high in Ethiopia (table 2). Employment-weighted dynamics attenuates the magnitude of turnover but leaves the qualitative outcomes intact. The only exception is the story on entrants which will be discussed later on. As show in appendix table A3, employment-weighted 34\% of firms in the bottom quintile of 1996 exited the market before 2002, which is nearly five times the rate of exit (7.4\%) from the top quintile. However, the tenacity of relative efficiency seems to be magnified when transition is weighted by employment. About 46\% of firms in the top quintile in 1996 
remained in the same quintile after 6 years, while a weighted $32 \%$ moved down to the second quintile. The increase in the degree of persistence at the top of the distribution and the attenuation in exit rates when transition is weighted by employment indicate that employment is concentrated among the most productive firms. It also shows that exiting firms are relatively small in size. ${ }^{10}$ Employment-weighted exit rates are also much more comparable with that of U.S. manufacturing although they are still on the higher side.

Table A3 differs from table 2 in one important aspect, that is, the distribution of entrants. Unlike table 2 where $50 \%$ of entrants are in the bottom two quintiles, employment-weighted entrants seem to be highly represented in the top two quintiles. A weighted $34.6 \%$ and $15 \%$ of entrants are in the first and second quintiles in the 2002 productivity ranking. This information reveals that most entrants are small firms located at the bottom of the productivity distribution and account for a relatively small fraction of manufacturing employment. It also shows that a handful of entrants that feature among the top-ranking incumbents are relatively large in size. This indicates that size and productivity are closely related and that the vintage effect that would have put most entrants at the top of the productivity distribution is simply not evident. Given that employment is concentrated among highly productive producers, which tend to maintain their relative efficiency, the high (unweighted) producer turnover rate in table 2 does not imply high employee turnover.

Notwithstanding the similarities highlighted above, the productivity dynamics reported in this article differ in important ways from the results in Baily et al. (1992) for U.S. manufacturing. ${ }^{11}$ For instance, the relationship between a firm's current and future relative productivity seems to be stronger in U.S. than in Ethiopian manufacturing. This is shown by the relatively higher degree of persistence in the top quintile for U.S. manufacturing (by nearly 5 percentage points) as compared to that of Ethiopia. Another side of this difference is that the probability of exit among highly efficient firms in Ethiopia is nearly twice as high as in the United States. This high producer turnover in Ethiopia bears similarity with the findings for Latin American semi-industrialized countries, where turnover rates are higher than in established market economies like Canada and the United States. One reason for such difference in the rate of turnover is the composition of manufacturing in developing countries which is dominated by low-technology consumer goods

${ }^{10}$ The median size of exiters, entrants, and continuing firms is 16,18 , and 44 persons, respectively.

${ }^{11}$ Comparisons with Baily et al. (1992) in the following sections are based on appendix table A3 with unweighted transition matrices for the period 1972-77. 
industries that require relatively small start-up capital. In this situation, exit may not be too costly for troubled firms. Financial constraints as well as political and macroeconomic instability in most developing countries may also induce firms not to enter with large production capacity (Tybout 2000).

Most importantly, upgrading from the lowest quintile to the top two quintiles is more likely to happen in U.S. manufacturing than in Ethiopian manufacturing. In the latter, only $10 \%$ of the least efficient firms managed to upgrade to the top two quintiles as compared to $20.4 \%$ for the U.S. report in Baily et al. (1992). Since small firms (most of them new entrants) account for a good part of the bottom quintile, this comparison suggests that the prospect of small firm survival and growth is lower in sub-Saharan Africa relative to advanced economies. Such differences in postentry performance reflect wide differences in the business environment in the two countries. In fact, for least efficient firms in Ethiopia, exit is the most likely scenario at about $60 \%$, which is nearly twice as high as in the United States. About onethird of firms in the least efficient quintile in the United States actually stayed in the bottom two quintiles after 5 years compared with only 13\% in Ethiopia.

Baily et al. (1992) also find that new entrants in U.S. manufacturing account for less than one-third of the population of firms in each quintile except for the least efficient quintile, where they make up $38.4 \%$. This is very different from the Ethiopian case, where more than three-fourths of firms in the bottom two quintiles comprise new entrants (table 2). This is perhaps one of the reasons why Baily et al. (1992) did not find a significant contribution of net entry to overall productivity growth because entrants are not only small in size but also relatively few in number compared to developing countries. The nature of entry in Ethiopian manufacturing is comparable to that of Taiwan, where entrants played an important role for industrial growth during the 1970s and 1980s (Aw et al. 2001).

\section{Selection and International Competition}

In this section, transition matrices are compared among groups of industries with varying degrees of exposure to international competition. This would provide more insight into the selection process by showing whether competition from imports strengthens market forces. Two groups of industries are identified for this purpose: those with import penetration rates below the 50\% threshold and those with rates above it. ${ }^{12}$ Industries with relatively low in-

${ }^{12}$ Assuming no exports, an import penetration ratio of $50 \%$ means imports equal domestic production; therefore, an import penetration ratio greater than $50 \%$ implies imports to domestic production ratio of greater than $100 \%$. 
TABLE 3

HIGH AND LOW COMPETITION INDUSTRIES: RANKING OF FIRMS BY UNWEIGHTED PRODUCTIVITY INDEX

\begin{tabular}{|c|c|c|c|c|c|c|c|}
\hline \multirow{2}{*}{$\begin{array}{l}\text { Quintiles } \\
\text { in } 1996\end{array}$} & \multicolumn{6}{|c|}{ Quintiles in 2002} & \multirow[b]{2}{*}{ Row Tota } \\
\hline & 1 & 2 & 3 & 4 & 5 & Exit & \\
\hline \multirow[t]{2}{*}{1} & 43.75 & 20.31 & 14.06 & 4.69 & 1.56 & 15.63 & 100 \\
\hline & 37.50 & 12.50 & 7.14 & 5.36 & 1.79 & 35.71 & 100 \\
\hline \multirow[t]{2}{*}{2} & 18.46 & 16.92 & 10.77 & 7.69 & 3.08 & 43.08 & 100 \\
\hline & 16.07 & 17.86 & 14.29 & 7.14 & 1.79 & 42.86 & 100 \\
\hline \multirow[t]{2}{*}{3} & 15.63 & 14.06 & 14.06 & 6.25 & 6.25 & 43.75 & 100 \\
\hline & 16.07 & 10.71 & 10.71 & 7.14 & 8.93 & 46.43 & 100 \\
\hline \multirow[t]{2}{*}{4} & 4.62 & 15.38 & 6.15 & 9.23 & 4.62 & 60.00 & 100 \\
\hline & 8.93 & 14.29 & 10.71 & 10.71 & 5.36 & 50.00 & 100 \\
\hline \multirow[t]{2}{*}{5} & 4.62 & 6.15 & 9.23 & 3.08 & 15.38 & 61.54 & 100 \\
\hline & 5.26 & 7.02 & 12.28 & 7.02 & 12.28 & 56.14 & 100 \\
\hline \multirow[t]{2}{*}{ Entry } & 12.18 & 15.87 & 20.30 & 25.83 & 25.83 & & 100 \\
\hline & 12.16 & 18.02 & 19.37 & 24.32 & 26.13 & & 100 \\
\hline
\end{tabular}

Source. Author's computation based on CSA data.

Note. For each cell the upper number corresponds to high-competition industries while the lower number (in bold italics) corresponds to low-competition industries. Both upper and lower numbers are row relative frequencies, and they correspond with the upper numbers in table 2.

ternational competition, that is, less than $50 \%$ import penetration ratio, include Food and Beverages, Leather and Footwear, and Nonmetal industries. Industries with high international competition include Textile and Garments, Chemical and Plastics, Metal, Light Machinery, Printing and Paper, and Wood and Furniture.

In both high and low competition industries, the basic features observed above still obtain: that the probability of exit decreases with the productivity ranking of firms and that there is considerable degree of persistence at the top of the productivity distribution. Table 3, however, provides the extra insight that exit rates among inefficient firms are significantly higher in industries facing high competition from imports as compared to those industries where competition is relatively low. In the fourth quintile for instance, the exit rate is $60 \%$ among industries with high import competition and 50\% for those with low competition from imports. In the fifth quintile, the difference is $61.5 \%$ to $56 \% .{ }^{13}$ However, the exit rate from the top quintile is $15.6 \%$ in high competition industries, which is less than half of the corresponding rate for industries with low import competition, that is, $35.7 \%$. Exposure to international competition therefore tends to reduce the degree of tolerance of inefficient producers while increasing the probability of survival

${ }^{13}$ A two-sample $t$-test shows significantly higher firm exit rates from the fourth and fifth quintiles for industries with high import competition as compared to those with low import competition. For firms in the first quintile the difference in exit rate by trade orientation is also statistically significant but in the opposite direction. No significant differences were observed for firms in the second and third quintiles. 
for productive firms. ${ }^{14}$ Trade liberalization therefore seems to have a positive role inasmuch as turnover promotes industry level productivity growth.

Employment-weighted transition matrices (not reported here) indicate that employment is concentrated among efficient firms in both groups of industries. However, the degree of persistence at the top of the distribution is higher among industries with relatively less international competition. This indicates that part of the efficiency gain in industries with more exposure to international competition may involve downsizing, which reduces the degree of concentration of employment at the top of the distribution relative to protected industries (Baily, Bartelsman, and Haltiwanger 1996). The employmentweighted exit rates are much lower than the unweighted exit rates in both groups of industries, showing that exiting firms are predominantly small in size. However, the link between smallness and inefficiency appears to be stronger in industries with high import penetration rates as the employmentweighted exit rates are lower in this group of industries.

\section{Turnover and Industry Dynamics}

We have seen that industries comprise heterogeneous firms and that the processes of entry, survival, and exit reflect underlying differences in relative efficiency. In this section, I address the question, How important have these processes been for aggregate productivity growth?

\section{Decomposition of Productivity Growth}

The growth accounting or representative firm approach pays utmost attention to intrafirm productivity growth as the sole source of aggregate productivity growth. Research based on micro data reveals that firm entry and exit as well as reallocation of resources from less to more productive incumbents could also play an important role. Existing evidence, however, shows mixed results in the sense that reallocation does not always play a positive role for aggregate productivity, and in those cases where it does, the magnitude is widely different across countries and over time. This section first highlights the decomposition method used in Baily et al. (1992), which I will refer to as the BHC method, and compares the results with benchmarks from developed and developing countries.

${ }^{14}$ A regression of $\log$-TFP on dummy variables representing entry, exit, and survival status as well as dummies for firm size, age, and import competition shows no significant productivity difference between entrants and exiters at $5 \%$ while continuing firms are significantly more productive. Efficiency is also higher among firms facing high import competition. See appendix table A5 for regression results. 
Following the BHC method, the level of TFP in logarithms is calculated as follows:

$$
\ln \mathrm{TFP}_{\mathrm{it}}=y_{i t}-\beta^{\prime} x_{i t}
$$

where $\mathrm{TFP}_{i t}$ is productivity of firm $i$ in period $t, y_{i t}$ is logarithm of value added, $x_{i t}$ is a vector of inputs in logarithms, and $\beta$ is a vector of factor elasticities. Industry-level aggregate TFP is simply a weighted sum of establishment-level TFP where value added shares are used as weights. Industry-level productivity growth between two periods has been calculated in accordance with the BHC method, or some variant of it:

$$
\Delta \ln \mathrm{TFP}_{t}=\sum_{i} s_{i t} \ln \mathrm{TFP}_{i t}-\sum_{i} s_{i, t-1} \ln \mathrm{TFP}_{i, t-1},
$$

where $s_{i t}$ represents establishment $i$ 's share in industry-level value added in period $t$.

Growth in aggregate productivity can then be decomposed into four components: intrafirm productivity growth with fixed shares, reallocation of market shares, a covariance term, and net entry. The decomposition method in this article follows the BHC approach as modified in Haltiwanger (1997) for unbalanced panel.

$$
\begin{gathered}
\sum_{i} s_{i t} \ln \operatorname{TFP}_{i t}-\sum_{i} s_{i, t-1} \ln \operatorname{TFP}_{i, t-1}= \\
{\left[\sum_{i \in c} s_{i, t-1} \Delta \ln \operatorname{TFP}_{i t}+\sum_{i \in c}\left(\ln \operatorname{TFP}_{i, t-1}-\ln \mathrm{TFP}_{t-1}\right) \Delta s_{i t}+\sum_{i \in c} \Delta s_{i t} \Delta \ln \mathrm{TFP}_{i t}\right]} \\
+\left[\sum_{i \in N} s_{i t}\left(\operatorname{lnTFP}_{i t}-\ln \operatorname{TFP}_{t-1}\right)-\sum_{i \in D} s_{i, t-1}\left(\operatorname{lnTFP}_{i, t-1}-\ln \mathrm{TFP}_{t-1}\right)\right] .
\end{gathered}
$$

The first block of terms in the right-hand side of (9) represents the contribution of continuing firms (represented by subscript $C$ ) to aggregate productivity growth, which is decomposed further into three components: (i) the first term is change in productivity weighted by initial market share, (ii) the second term is change in market share weighted by the deviation of initial firm-level productivity from initial industry mean, and (iii) the third item is a covariance term that combines changes in both productivity and market share. Most empirical applications lump the covariance term with the share effect to avoid ambiguity. The second block of terms, terms 4 and 5, represent net entry that is the share-weighted effect of entrants (represented by subscript $N$ ) after 
TABLE 4

DECOMPOSITION OF PRODUCTIVITY GROWTH AT THE MANUFACTURING SECTOR LEVEL: THE BAILY-HULTEN-CAMPBELL METHOD

\begin{tabular}{|c|c|c|c|c|c|}
\hline \multirow[b]{2}{*}{ (1) } & \multicolumn{2}{|c|}{ Industry Productivity Growth } & \multirow[b]{2}{*}{$\begin{array}{l}\text { Within Effect } \\
\text { (4) }\end{array}$} & \multirow[b]{2}{*}{$\begin{array}{l}\text { Reallocation Effect } \\
\text { (5) }\end{array}$} & \multirow[b]{2}{*}{$\begin{array}{l}\text { Net Entry } \\
\text { (6) }\end{array}$} \\
\hline & $\begin{array}{l}\text { Divisia Index } \\
\text { (2) }\end{array}$ & $\begin{array}{c}\text { BHC Aggregate } \\
\text { (3) }\end{array}$ & & & \\
\hline 1997 & -8.36 & -5.03 & -17.45 & 10.05 & 2.36 \\
\hline 1998 & -6.88 & -7.42 & -32.77 & 15.01 & 10.35 \\
\hline 1999 & 4.21 & .96 & -12.41 & 4.58 & 8.79 \\
\hline 2000 & -13.26 & -.73 & -33.65 & 39.61 & -6.68 \\
\hline 2001 & -.21 & -9.94 & -22.33 & 2.87 & 9.52 \\
\hline 2002 & -8.77 & -6.91 & -20.86 & 12.11 & 1.84 \\
\hline Period average & -5.55 & -4.85 & -23.25 & 14.04 & 4.36 \\
\hline
\end{tabular}

deducting the role of exiters (represented by subscript $D$ ). The latter two terms are expressed as share-weighted deviations from the industry mean in the base year. While following the BHC method, the productivity terms in this article are indexed to the industry mean in the base year. For a decomposition analysis based on unbalanced panel, the use of such deviations from the industry mean implies that entry (exit) contributes to industry-level productivity growth if the efficiency of entrants (exiters) is above (below) the mean industry practice in the base year (Haltiwanger 1997).

\section{Results of Decomposition Analysis}

The decomposition of annual productivity growth has been carried out for nine industries. The analysis in this section, however, is based on table 4, which provides decomposition results for the manufacturing sector. Industryspecific decompositions are reported in appendix table A4. In both tables the aggregate productivity growth based on the BHC method is compared with productivity growth based on the representative firm approximation. The latter is obtained by applying the Tornquist approximation to the Divisia index assuming a competitive market where factor shares in revenue represent factor elasticities. Weights for aggregation to the manufacturing sector level in table 4 are derived from the share of each industry in manufacturing value added during 1996-2002.

The second and third columns in table 4 and table A4 report year on year productivity growth based on the Divisia index and the BHC method, respectively. The two series tend to move together, showing that they capture a similar trend in productivity growth although the magnitudes differ. For instance, table 4 reports a productivity decline of $8.36 \%$ in 1997 according to the growth account method while the BHC method shows a $5.03 \%$ decline. It is important to note that (the logarithm of) firm-level productivity has been indexed to the representative firm in the base year such that an increase 
in market share for a particular firm would contribute to industry productivity growth only if the firm was above the industry average in the base year. Similarly, a decline in market share could boost industry productivity if the firm's efficiency was below the mean industry practice in the base year.

The most important and clear observation emerging from this exercise is that productivity has been declining in Ethiopian manufacturing during the period under investigation. As shown in the last row of table 4, both approaches report comparable rates of productivity decline for the period 1996-2002, that is, $-5.55 \%$ in the case of the Divisia index and $-4.85 \%$ in the BHC method. Except for the Textile and Light Machinery industries, where productivity grew for 3 years in a row during 1998-2000, it is hard to find industries with a steady productivity growth (see table A4). The decomposition also shows that the within effect has been the major source of aggregate productivity decline. Looking at table 4 , the entire productivity decline was actually due to intrafirm productivity decline. Table A4 also shows that the within effect has been negative for more than $80 \%$ of the (annual) observations on productivity growth for the nine industries. This result is consistent with the findings of decomposition analysis for developed and developing countries where the intrafirm productivity growth/decline determines the path of productivity at the industry level (Baily et al. 1992; Griliches and Regev 1995; Aw et al. 2001).

The reallocation of resources from less efficient to more productive incumbents has played a positive role with few exceptions. For the manufacturing sector as a whole, table 4 shows that reallocation of resources has managed to offset on average $60 \%$ of the productivity decline that would have occurred due to intrafirm productivity decline. Although it did not completely offset the negative trend in intrafirm productivity, market selection has mitigated the decline in aggregate TFP by shifting output toward more efficient firms. Looking at individual industries, table $\mathrm{A} 4$ shows that the reallocation effect offsets a potential $40 \%$ TFP decline in the Food and Metal industries, and more than $60 \%$ of the decline in other industries. Such positive reallocation effects have also been reported in Baily et al. (1992) and Haltiwanger (1997) for U.S. manufacturing. While the within effect is greater than the reallocation effect during periods of productivity growth, the latter remains positive and offsets more than $70 \%$ of the decline due to the within effect during periods of productivity decline (Baily et al. 1992). This is, however, different from the results reported in Aw et al. (2001) and Liu and Tybout (1996) for Taiwan and Colombia, respectively. For these countries, shifts in market share among incumbents played little or no positive role for aggregate productivity.

Table 4 also reveals that producer turnover made a positive contribution to 
productivity growth in Ethiopian manufacturing. The net-entry term was positive for all years except 2000, showing that share-weighted productivity of entrants was greater than that of exiting firms. Looking at the manufacturing sector over the entire study period, net entry has offset about $19 \%$ of the downturn in productivity that would have occurred due to the negative intrafirm effect. At the industry level, table A4 shows that net entry has been a source of productivity growth in five out of nine industries during the study period.

The positive net-entry effect in Ethiopian manufacturing is much higher than that in the findings of Baily et al. (1992) for the United States, where it played essentially no significant role. At 4.5 percentage points on average, the evidence from Ethiopia appears to be comparable to that of Taiwan in term of percentage points. However, its overall contribution to industry-level productivity growth is far less than in Taiwan, where it accounted for nearly half of the productivity growth during 1981-86 (Aw et al. 2001). The reason why net entry played a huge role in Taiwan has to do with the large difference in the productivity of entrants and exiters as well as the relatively large share of entrants in total output. Net entry did not play a significant role in U.S. manufacturing for the exact opposite reasons. The Ethiopian case appears to be somewhere in between, with entrants and exiters showing very little productivity differences, ${ }^{15}$ but entrants as a group account for a sizable market share compared to exiters. Firms that were going to exit the market during the 5 years leading to 2002 accounted for about $8 \%$ of the market share in 1996 while firms that joined manufacturing since 1997 accounted for more than a quarter of industrial output in 2002. The latter has little to do with entrants being significantly larger than exiters-the median entrant has 18 employees while the median exiter has 16 employees. However, Ethiopian manufacturing is being dominated by new entrants that are not significantly more efficient or larger than exiters but collectively account for a significant share of manufactured output. This is consistent with the results in table 2 where entrants account for one-third to three-fourths of all firms in each quintile in 2002.

The positive role played by producer turnover and the reallocation of market shares toward more efficient firms shows that markets are functioning well and have contributed to productivity growth. However, these contributions have at best managed to mitigate the more pervasive intrafirm productivity decline that continues to drive a downward spiral in industry productivity. Unleashing market forces, therefore, does not guarantee on its own that in-

${ }^{15}$ See n. 11 above. 
dustries in developing countries will be on a long-term competitive path. Reshuffling of resources has its limits as firms will discover sooner or latter the competitive advantages of the most productive firms as models of market selection indicate. Although perfect imitation of best practices may not be possible due to intangible elements, the gap is expected to narrow over time leaving small room for improvement through reallocation (Petrin and Levinsohn 2004). A long-term development strategy will have to look beyond the disciplinary and allocative role of markets and explore factors that determine intrafirm technological capabilities.

\section{Conclusion}

The analysis of micro panel data from Ethiopian manufacturing shows considerable degree of firm-level heterogeneity that is very similar to observations from other countries. There is also evidence that the observed patterns of firm entry, exit, and survival are underpinned by productivity differences. Although efficiency is not the only factor behind the observed dynamics, data show that highly efficient firms are more likely to remain at the top of the productivity distribution while firms at the lower tail of the productivity distribution exit more frequently. It has been shown that industries with relatively high import penetration rate demonstrate less tolerance to inefficient firms, suggesting that liberalization may have a positive role as long as turnover contributes to productivity growth. Producer turnover rates in Ethiopia have been higher than in advanced economies like that of the United States. In general, though, the observed patterns of firm dynamics corroborate research findings from other developed and developing regions, showing that markets in sub-Saharan African, as represented by Ethiopia, are at least as strong as those of other regions in forcing inefficient businesses to close down.

In conformity with the assumptions of market selection models, most entrants join an industry with relatively small size at the lower end of the productivity distribution and tend to pass through a process of learning that leads either to upgrading in the productivity ladder or exit. Since entry and exit take place predominantly among less efficient firms which are also small in size, the immediate contribution of producer turnover to aggregate productivity does not appear to be very big. However, its long-term effect is expected to be high as entrants collectively account for a significant share of industry output and pose a competitive challenge for incumbents. There is also a significant amount of industry rationalization as market shares are reallocated from less efficient to more efficient incumbents. This process has managed to counteract the negative effect of a more or less secular decline in intrafirm productivity during the study period. 
As in other countries, intrafirm productivity growth determines the path of aggregate productivity in almost all industries and time periods. Its declining trend in most industries in Ethiopia requires further investigation. There are preliminary indications that the proportion of firms with nonzero investment (which stands at slightly less than 50\%) has shown no improvement with the actual rate of investment also tending to decline. Improving the investment climate would thus play a crucial role in reversing the negative trend in intrafirm productivity. Finally, it can be concluded that while markets have played the expected disciplinary role in sub-Saharan Africa, they are not sufficient on their own to help a developing economy acquire long-term competitiveness. 


\section{Appendix}

TABLE A1

BASIC FEATURES OF ETHIOPIAN MANUFACTURING

\begin{tabular}{|c|c|c|c|c|c|c|c|c|c|c|c|c|c|c|}
\hline & \multicolumn{2}{|c|}{$\begin{array}{l}\text { Distribution of } \\
\text { Firms by } \\
\text { Industry (\%) }\end{array}$} & \multirow{2}{*}{$\begin{array}{c}\text { Four Firm } \\
\text { Concentration } \\
\text { Ratio }(\%)^{\star} \\
1996-2002\end{array}$} & \multirow{2}{*}{$\begin{array}{c}\text { Capital per } \\
\text { Worker } \\
\text { (Thousands } \\
\text { of Birr)* } \\
\text { 1996-2002 }\end{array}$} & \multirow{2}{*}{$\begin{array}{c}\text { Import } \\
\text { Penetration } \\
\text { Ratio }(\%)^{\star} \\
1996-2002\end{array}$} & \multicolumn{2}{|c|}{$\begin{array}{c}\text { Public } \\
\text { Enterprises } \\
\text { (\%) }\end{array}$} & \multicolumn{2}{|c|}{$\begin{array}{c}\text { Employment } \\
\text { in Public } \\
\text { Enterprises } \\
(\%)\end{array}$} & \multicolumn{2}{|c|}{$\begin{array}{l}\text { Enterprises } \\
\text { with Foreign } \\
\text { Capital (\%) }\end{array}$} & \multicolumn{3}{|c|}{$\begin{array}{c}\text { Size Distribution } \\
\text { of Firms (\%) } \\
\text { (Average 1996-2002) }\end{array}$} \\
\hline & 1996 & 2002 & & & & 1996 & 2002 & 1996 & 2002 & 1996 & 2002 & Small & Medium & Large \\
\hline Food and Beverage & 24.6 & 29.4 & 41.4 & 52.9 & 14.0 & 31.8 & 14.5 & 86.1 & 57.6 & .0 & 3.2 & 57.4 & 18.3 & 24.3 \\
\hline Textile and Garments & 10.0 & 8.0 & 35.0 & 32.2 & 48.8 & 50.0 & 34.3 & 97.0 & 64.2 & 4.8 & 7.5 & 32.3 & 22.9 & 44.9 \\
\hline Leather and Footwear & 10.1 & 5.9 & 49.4 & 86.5 & 30.8 & 14.8 & 13.7 & 74.2 & 52.7 & 6.6 & 9.8 & 46.3 & 28.0 & 25.8 \\
\hline Wood and Furniture & 16.2 & 19.0 & 40.9 & 16.0 & 54.2 & 17.8 & 7.4 & 54.8 & 22.6 & 5.0 & 3.4 & 72.4 & 17.8 & 9.9 \\
\hline Printing and Paper & 6.9 & 8.3 & 61.7 & 30.1 & 48.7 & 21.4 & 12.5 & 80.8 & 63.4 & 4.8 & 2.8 & 55.0 & 30.6 & 14.4 \\
\hline Chemical and Plastics & 8.2 & 9.0 & 47.1 & 81.9 & 69.0 & 27.5 & 19.0 & 77.5 & 46.1 & .0 & 8.9 & 48.0 & 25.6 & 26.5 \\
\hline Nonmetal & 13.2 & 10.8 & 78.6 & 32.6 & 21.2 & 24.6 & 23.0 & 74.0 & 74.1 & 4.3 & 1.4 & 60.8 & 20.8 & 18.4 \\
\hline Metal & 7.2 & 7.7 & 77.5 & 50.9 & 61.1 & 15.6 & 10.6 & 62.9 & 46.6 & 11.1 & 9.1 & 62.1 & 23.0 & 14.9 \\
\hline Light Machinery & 3.5 & 1.9 & 87.2 & 52.3 & 98.3 & 13.6 & 17.7 & 70.5 & 68.2 & 9.1 & 23.5 & 69.5 & 19.9 & 10.6 \\
\hline Number of Firms & 605 & 823 & & & & 157 & 129 & & & 24 & 44 & & & \\
\hline
\end{tabular}

Source. Author's computation based on CSA data.

*Average for 1996-2002. 
TABLE A2

ESTIMATES OF PRODUCTION FUNCTIONS (DEPENDENT VARIABLE LOG VALUE ADDED)

\begin{tabular}{|c|c|c|c|}
\hline \multirow[b]{2}{*}{$\begin{array}{l}\text { Industry } \\
\text { (1) }\end{array}$} & \multicolumn{2}{|c|}{ Levinsohn-Petrin } & \multirow{2}{*}{$\begin{array}{l}\text { Number of } \\
\text { Observations } \\
\text { (4) }\end{array}$} \\
\hline & $\begin{array}{l}\text { Labor } \\
(2)\end{array}$ & $\begin{array}{c}\text { Capital } \\
\text { (3) }\end{array}$ & \\
\hline Food and Beverage & $.806(.085)$ & $.484(.092)$ & 1,335 \\
\hline Textile and Garments & $.394(.100)$ & $.307(.248)$ & 372 \\
\hline Leather and Footwear & $.595(.156)$ & $.330(.327)$ & 271 \\
\hline Wood and Furniture & $.729(.070)$ & $.048(.368)$ & 836 \\
\hline Printing and Paper & $.839(.175)$ & $.449(.239)$ & 302 \\
\hline Chemical and Plastics & $.624(.104)$ & $.538(.285)$ & 239 \\
\hline Nonmetal & $.909(.152)$ & $.041(.328)$ & 470 \\
\hline Basic Metal & $.610(.126)$ & $.535(.211)$ & 196 \\
\hline Light Machinery & $.717(.132)$ & $.313(.158)$ & 101 \\
\hline
\end{tabular}

Note. Bootstrapped standard errors (200 replications) are in parentheses.

TABLE A3

RANKING OF FIRMS BASED ON EMPLOYMENT WEIGHTED PRODUCTIVITY INDEX

\begin{tabular}{|c|c|c|c|c|c|c|c|}
\hline \multirow{2}{*}{$\begin{array}{l}\text { Quintiles in } \\
1996 \text { and } \\
\text { Rank }\end{array}$} & \multicolumn{6}{|c|}{ Quintiles in 2002} & \multirow{2}{*}{$\begin{array}{l}\text { U.S. } \\
\text { Exit } \\
\text { Rate }\end{array}$} \\
\hline & 1 & 2 & 3 & 4 & 5 & Exit & \\
\hline 1 & 46.1 & 31.9 & 10.0 & 1.9 & 2.7 & 7.4 & 6.27 \\
\hline 2 & 51.0 & 33.5 & 2.3 & 6.2 & .3 & 6.7 & 8.20 \\
\hline 3 & 9.5 & 23.9 & 47.9 & 6.9 & 2.6 & 9.1 & 8.73 \\
\hline 4 & 8.5 & 14.4 & 39.3 & 10.5 & 8.9 & 18.5 & 12.27 \\
\hline 5 & 1.7 & 4.7 & 29.3 & 14.7 & 15.4 & 34.2 & 11.23 \\
\hline Entry & 36.6 & 15.0 & 18.3 & 14.8 & 17.3 & & \\
\hline U.S. entry rate & 20.79 & 18.66 & 13.82 & 17.44 & 29.3 & & \\
\hline
\end{tabular}

Source. Author's computation.

Note. The numbers in each cell are row relative frequencies and correspond to the upper numbers in table 2. Exit rates for U.S. manufacturing are taken from Baily et al. (1992, 213, table 3) and refer to "switching-out" plus "death," whereas entry rates refer only to entry through "birth."

TABLE A4

DECOMPOSITION OF INDUSTRY PRODUCTIVITY GROWTH: THE BAILY-HULTEN-CAMPBELL METHOD

\begin{tabular}{|c|c|c|c|c|c|}
\hline \multirow[b]{2}{*}{ (1) } & \multicolumn{2}{|c|}{ Industry Productivity Growth } & \multirow[b]{2}{*}{$\begin{array}{l}\text { Within Effect } \\
\text { (4) }\end{array}$} & \multirow[b]{2}{*}{$\begin{array}{l}\text { Reallocation Effect } \\
\text { (5) }\end{array}$} & \multirow[b]{2}{*}{$\begin{array}{l}\text { Net Entry } \\
\text { (6) }\end{array}$} \\
\hline & $\begin{array}{l}\text { Divisia Index } \\
\text { (2) }\end{array}$ & $\begin{array}{c}\text { BHC Aggregate } \\
\text { (3) }\end{array}$ & & & \\
\hline \multicolumn{6}{|c|}{ Food and Beverage: } \\
\hline 1997 & -15.52 & -7.07 & -15.46 & 7.74 & .65 \\
\hline 1998 & -1.21 & -.54 & -9.92 & 4.84 & 4.54 \\
\hline 1999 & -1.08 & -11.71 & -6.53 & -25.17 & 19.99 \\
\hline 2000 & -27.30 & -4.97 & -48.54 & 50.33 & -6.76 \\
\hline 2001 & 25.17 & 4.94 & -1.41 & -3.26 & 9.61 \\
\hline 2002 & -13.75 & -9.89 & -12.65 & 2.51 & .26 \\
\hline \multicolumn{6}{|c|}{ Textile and Garments: } \\
\hline 1997 & -10.10 & -23.47 & -18.34 & 1.29 & -6.42 \\
\hline 1998 & 17.30 & 10.22 & -29.59 & 39.97 & -.11 \\
\hline 1999 & 50.44 & 42.10 & 17.14 & 24.87 & .09 \\
\hline 2000 & 15.63 & 14.59 & -21.36 & 22.84 & 13.11 \\
\hline 2001 & -38.17 & -41.09 & -56.81 & 9.09 & 6.63 \\
\hline 2002 & -1.38 & -13.29 & -44.62 & 31.08 & .25 \\
\hline
\end{tabular}


TABLE A4 (Continued)

\begin{tabular}{|c|c|c|c|c|c|}
\hline \multirow[b]{2}{*}{ (1) } & \multicolumn{2}{|c|}{ Industry Productivity Growth } & \multirow[b]{2}{*}{$\begin{array}{l}\text { Within Effect } \\
\text { (4) }\end{array}$} & \multirow[b]{2}{*}{$\begin{array}{l}\text { Reallocation Effect } \\
\text { (5) }\end{array}$} & \multirow[b]{2}{*}{$\begin{array}{l}\text { Net Entry } \\
\text { (6) }\end{array}$} \\
\hline & $\begin{array}{l}\text { Divisia Index } \\
\text { (2) }\end{array}$ & $\begin{array}{c}\text { BHC Aggregate } \\
\text { (3) }\end{array}$ & & & \\
\hline \multicolumn{6}{|c|}{ Leather and Footwear: } \\
\hline 1997 & 31.80 & -5.73 & -22.54 & -17.86 & 34.66 \\
\hline 1998 & -44.52 & -97.38 & -127.07 & 29.65 & .04 \\
\hline 1999 & 59.80 & 148.45 & -1.14 & 144.59 & 5.00 \\
\hline 2000 & -84.75 & -157.67 & -105.39 & 46.55 & -98.83 \\
\hline 2001 & -58.12 & -29.87 & -119.14 & 31.38 & 57.89 \\
\hline 2002 & -.09 & -37.20 & -73.99 & 36.98 & -.19 \\
\hline \multicolumn{6}{|c|}{ Wood and Furniture: } \\
\hline 1997 & 17.24 & 5.30 & -7.99 & 26.50 & -13.20 \\
\hline 1998 & 17.26 & 23.36 & 2.78 & 9.96 & 10.61 \\
\hline 1999 & -44.00 & -25.46 & -68.93 & 42.56 & .91 \\
\hline 2000 & -5.26 & 5.36 & -14.87 & 23.22 & -2.98 \\
\hline 2001 & 4.97 & 3.08 & -5.43 & 12.35 & -3.84 \\
\hline 2002 & -27.76 & -19.23 & -37.12 & 25.01 & -7.12 \\
\hline \multicolumn{6}{|c|}{ Printing and Paper: } \\
\hline 1997 & -13.75 & -1.30 & -2.56 & 27.66 & -26.37 \\
\hline 1998 & 15.34 & -3.50 & 14.86 & -28.61 & 10.25 \\
\hline 1999 & 11.45 & -1.32 & -5.92 & 5.07 & -.47 \\
\hline 2000 & -56.68 & -26.75 & -61.48 & 32.12 & 2.61 \\
\hline 2001 & 39.04 & 52.08 & 28.05 & 26.48 & -2.45 \\
\hline 2002 & -19.63 & -53.17 & -50.37 & -2.48 & -.33 \\
\hline \multicolumn{6}{|c|}{ Chemical and Plastics: } \\
\hline 1997 & 2.74 & 2.00 & -43.21 & 24.95 & 20.25 \\
\hline 1998 & 5.48 & 12.96 & -60.06 & 15.28 & 57.74 \\
\hline 1999 & -30.33 & -26.16 & -55.57 & 22.50 & 6.92 \\
\hline 2000 & 55.18 & 77.63 & 33.80 & 43.24 & .60 \\
\hline 2001 & -37.96 & -57.53 & -54.79 & -2.63 & -.11 \\
\hline 2002 & -7.18 & 12.48 & -12.97 & 20.82 & 4.63 \\
\hline \multicolumn{6}{|c|}{ Nonmetal: } \\
\hline 1997 & 8.11 & 13.62 & -7.48 & 20.63 & .48 \\
\hline 1998 & -44.46 & -4.10 & -82.88 & 79.92 & -1.14 \\
\hline 1999 & 15.96 & 26.52 & 37.45 & 24.20 & -35.14 \\
\hline 2000 & -24.15 & -20.99 & -40.16 & 20.23 & -1.06 \\
\hline 2001 & -36.60 & -32.33 & -30.93 & 3.47 & -4.87 \\
\hline 2002 & 22.77 & 20.25 & 14.67 & 6.02 & -.43 \\
\hline \multicolumn{6}{|l|}{ Metal: } \\
\hline 1997 & -19.46 & -2.21 & -5.08 & -6.22 & 9.09 \\
\hline 1998 & -76.43 & -82.76 & -108.78 & 15.95 & 10.07 \\
\hline 1999 & -7.46 & -39.18 & -74.13 & 34.94 & .01 \\
\hline 2000 & 35.22 & 39.54 & 21.25 & 16.66 & 1.62 \\
\hline 2001 & -28.87 & -20.35 & -48.89 & 2.92 & 25.62 \\
\hline 2002 & -9.55 & 31.56 & -30.45 & 37.43 & 24.58 \\
\hline \multicolumn{6}{|c|}{ Light Machinery: } \\
\hline 1997 & -31.61 & -.28 & -52.20 & 56.37 & -4.46 \\
\hline 1998 & 29.18 & 50.18 & 6.77 & 39.34 & 4.07 \\
\hline 1999 & 22.95 & -10.57 & 15.40 & -26.76 & .79 \\
\hline 2000 & 6.25 & -4.52 & -.03 & -30.99 & 26.49 \\
\hline 2001 & -18.42 & -19.24 & -18.71 & -1.33 & .38 \\
\hline 2002 & 15.66 & 12.53 & 8.57 & 19.74 & -15.77 \\
\hline
\end{tabular}

Source. Author's computation. 
TABLE A5

OLS REGRESSION OF (LOG) TOTAL FACTOR PRODUCTIVITY

\begin{tabular}{lrrr}
\hline & Coefficient & Standard Error & T-Statistic \\
\hline Medium size firms & .5492 & .0442 & 12.43 \\
Large firms & .6426 & .0486 & 13.21 \\
Entrants & -.0874 & .0530 & -1.65 \\
Continuing firms & .2657 & .0505 & 5.26 \\
Import competing & .2900 & .0714 & 4.06 \\
Ages 5-9 & .1092 & .0556 & 1.96 \\
Ages 10-19 & .1347 & .0526 & 2.56 \\
Ages 20-29 & .3136 & .0514 & 6.11 \\
Ages 30+ & .4284 & .0581 & 7.37 \\
Intercept & -.4906 & .0560 & -8.77 \\
Number of observations & 4,323 & & \\
$R^{2}$ & .16 & & \\
\hline
\end{tabular}

Note. Firms that employ 10-29 persons are considered to be small; medium size firms employ 30-99 persons; and large firms employ at least 100 employees. "Entrants" is a dummy variable that takes the value 1 for firms that joined the manufacturing sector after 1996 and "Continuing firms" is a dummy variable representing firms observed in both 1996 and 2002. Exiters are those firms observed in 1996 but not in 2002. The reference category includes exiting small firms in non-import-competing industries that are less than 5 years old. Age and size are measured at first period of observation in the sample. Although the model controls for industryspecific effects, the coefficients are bound to be biased due to unobserved variation that correlates with covariates in the model.

\section{References}

Ackerberg, Daniel A., Kevin Caves, and Garth Frazer. 2005. "Structural Identification of Production Functions.” Photocopy, Department of Economics, Yale University.

Aw, Bee-Yan, Xiaomin Chen, and Mark J. Roberts. 2001. "Firm-Level Evidence on Productivity Differentials, Turnover, and Exports in Taiwanese Manufacturing." Journal of Development Economics 66 (October): 51-86.

Baily, Martin N., Eric J. Bartelsman, and John C. Haltiwanger. 1996. "Downsizing and Productivity Growth: Myth or Reality?” Small Business Economics 8, no. 4: 259-78.

Baily, Martin N., Charles Hulten, and David Campbell. 1992. "Productivity Dynamics in Manufacturing Plants." Brookings Papers: Microeconomics, 1992, 187-249.

Bartelsman, Eric J., and Mark Doms. 2000. "Understanding Productivity: Lessons from Longitudinal Microdata." Journal of Economic Literature 38 (September): 569-94.

Battese, George E., and Tim J. Coelli. 1992. "Frontier Production Functions, Technical Efficiency and Panel Data: With Applications to Paddy Farmers in India." Journal of Productivity Analysis 3:153-69.

Bernard, Andrew, and J. Bradford Jensen. 1999. "Exceptional Exporter Performance: Cause, Effects, or Both?” Journal of International Economics 47 (February): 1-25.

Collier, Paul, and Jan Willem Gunning. 1999. "Explaining African Economic Performance." Journal of Economic Literature 37 (March): 64-111.

Cornwell, Christopher, Peter Schmidt, and Robin C. Sickles. 1990. "Production 
Frontiers with Cross-Sectional and Time-Series Variations in Efficiency Levels." Journal of Econometrics 46:185-200.

Ericson, Richard, and Ariel Pakes. 1995. "Markov-Perfect Industry Dynamics: A Framework for Empirical Work." Review of Economic Studies 62 (January): 53-82.

Evans, S. David. 1987. "The Relationship between Firm Growth, Size, and Age: Estimates for 100 Manufacturing Industries." Journal of Industrial Economics 34, no. 4:567-81.

Frazer, Garth. 2005. "Which Firms Die? A Look at Manufacturing Firm Exit in Ghana." Economic Development and Cultural Change 53 (April): 585-617.

Griliches, Zvi, and Jacques Mairesse. 1998. "Production Functions: The Search for Identification." In Econometrics and Economic Theory in the Twentieth Century: The Ragnar Frisch Centennial Symposium, ed. S. Strom. Cambridge: Cambridge University Press.

Griliches, Zvi, and Haim Regev. 1995. "Firm Productivity in Israeli Industry: 1979-1988." Journal of Econometrics 65 (January): 175-230.

Gunning, Jan Willem, and Taye Mengistae. 2001. "Determinants of African Manufacturing Investment: The Microeconomic Evidence." Journal of African Economies 10 , no. $2: 48-80$.

Haltiwanger, John C. 1997. "Measuring and Analyzing Aggregate Fluctuations: The Impact of Building from Microeconomic Evidence." Federal Reserve Bank St. Louis Review 79, no. 3:55-77.

Hopenhayn, Hugo. 1992. "Entry, Exit, and Firm Dynamics in Long Run Equilibrium." Econometrica 60, no. 5:1127-50.

Jovanovic, Boyan. 1982. "Selection and the Evolution of Industry." Econometrica 50, no. 3:649-70.

Lall, Sanjaya. 2001. Competitiveness, Technology and Skills. Cheltenham: Elgar.

Levinsohn, James, and Amil Petrin. 2003. "Estimating Production Functions Using Inputs to Control for Unobservables." Review of Economic Studies 70 (April): 317-41.

Liedholm, Carl, and Donald C. Mead. 1999. Small Enterprises and Economic Development. London: Routledge.

Liu, Lili, and James R. Tybout. 1996. "Productivity Growth in Colombia and Chile: Panel-Based Evidence on the Role of Entry, Exit and Learning." In Industrial Evolution in Developing Countries, ed. Mark Roberts and James R. Tybout. New York: Oxford University Press.

Lucas, Robert E. 1993. "Making a Miracle." Econometrica 61, no. 2:251-72.

McPherson, Michael A. 1995. "The Hazard of Small Firms in Southern Africa." Journal of Development Studies 32 (October): 31-54.

Noorbakhsh, Farhad, and Alberto Paloni. 1998. "Structural Adjustment Programmes and Export Supply Response." Journal of International Development 10:555-73.

Olley, Steve, and Ariel Pakes. 1996. "The Dynamics of Productivity in the Telecommunications Equipment Industry." Econometrica 64, no. 6:1263-97.

Pavcnik, Nina. 2002. "Trade Liberalization, Exit and Productivity Improvement: Evidence from Chilean Plants." Review of Economic Studies 69 (January): 245-76.

Petrin, Amil, and James Levinsohn. 2004. "Measuring and Mismeasuring Industry Productivity Growth Using Plant-Level Data." Photocopy, Graduate School of Business, University of Chicago. 
Petrin, Amil, Brian P. Poi, and James Levinsohn. 2004. "Production Function Estimation in Stata Using Inputs to Control for Unobservables." Stata Journal 4, no. 2:113-23.

Söderbom, Måns, Francis Teal, and Alan Harding. 2006. "The Determinants of Survival among African Manufacturing Firms." Economic Development and Cultural Change 54 (April): 533-55.

Stockey, Nancy L. 1991. "Human Capital, Product Quality and Growth." Quarterly Journal of Economics 106, no. 2:587-616.

Tybout, James R. 2000. "Manufacturing Firms in Developing Countries: How Well Do They Do, and Why?" Journal of Economic Literature 38 (March): 11-44.

Van Biesebroeck, Johannes. 2005. "Firm Size Matters: Growth and Productivity Growth in African Manufacturing." Economic Development and Cultural Change 53 (April): 545-83. 